\title{
Promiscuous functions of the prion protein family
}

\section{Sophie Mouillet-Richard ${ }^{1,2 *}$ and Jean-Luc Vilotte ${ }^{3}$}

\author{
Toxicology, Pharmacology, and Cellular Signaling, Institut National de la Santé et de la Recherche Médicale Unité Mixtes de Recherche-S1124, Université Paris \\ Descartes, Paris, France \\ 2 Toxicology, Pharmacology, and Cellular Signaling, Sorbonne Paris Cité, Unité Mixtes de Recherche-S1124, Université Paris Descartes, Paris, France \\ ${ }^{3}$ Unité Mixtes de Recherche1313 Génétique Animale et Biologie Intégrative, Institut National de la Recherche Agronomique, Jouy-en-Josas, France \\ *Correspondence: sophie.mouillet-richard@parisdescartes.fr
}

Edited and reviewed by:

Craig Michael Walsh, University of California, Irvine, USA

Keywords: prion protein, embryonic and fetal development, stem cells, aging, cell signaling, placenta, gonads, neuroprotection

From the discovery nearly 30 years ago of the cellular prion protein $\operatorname{PrP}^{\mathrm{C}}$, the founder of the prion protein family, there has been a constant quest to dissect its biological function and that of its two homologs, Doppel and Shadoo. While clues were greatly anticipated from the generation of PrP null mice, alterations appeared quite imperceptible at first examination, beyond the clear-cut resistance to prion infection. Taking a closer look at these knockout mice, together with the generation of mice invalidated for Doppel and Shadoo has in the end yielded much information on the -sometimes overlapping- roles of these proteins. These in-depth investigations have also explored functions of the prion protein family beyond the central nervous system, which was obviously the first focus of interest since prion diseases are neurodegenerative disorders. This Frontiers Research topic on the promiscuous functions of the prion protein family incorporates contributions ranging from the field of developmental biology to that of structure-function, including aspects related to cell biology, signal transduction, and neuronal homeostasis.

Starting from the embryo, the contribution by Halliez et al. provides a comprehensive review of the impact of $\operatorname{PrP}$ invalidation on embryonic development, compiling data from both mice and zebrafish and highlighting the key cellular pathways affected by $\operatorname{PrP}^{\mathrm{C}}$ deletion (Halliez et al., 2014). The review by Makzhami and colleagues is centered on the tissue with the second highest $\mathrm{PrP}^{\mathrm{C}}$ expression after the brain, i.e., the placenta (Makzhami et al., 2014). It summarizes the recent data obtained with the help of $\operatorname{PrP}$ invalidated mice and discusses the pathophysiological implications stemming from the aberrant $\mathrm{PrP}^{\mathrm{C}}$ expression in human gestational diseases. The review by AllaisBonnet and Pailhoux is dedicated to the gonads, a unique tissue where $\operatorname{PrP}^{\mathrm{C}}$, Shadoo and Doppel are all expressed, raising the question of a potential redundancy between the three proteins, as well as their roles in reproductive functions (Allais-Bonnet and Pailhoux, 2014). Mehrabian et al. provide a perspective on the potential relationship between $\operatorname{PrP}^{\mathrm{C}}$ and the pathways involved in epithelial to mesenchymal transition, a process associated with major changes in cell adhesion properties and that physiologically takes place during embryonic development, while also involved in cancer metastasis (Mehrabian et al., 2014). A further connection with cancer is highlighted in the mini-review by Martin-Lannerée et al, which focuses on the contribution of $\operatorname{PrP}^{\mathrm{C}}$ to stem cell biology and its recent association with tumor-initiating cells (Martin-Lanneree et al., 2014). At a cellular level, Sakudo and Onodera provide an overview of the data gathered by exploiting cell lines derived from PrP-null mice or constitutively knocked-down for $\operatorname{PrP}^{\mathrm{C}}$, with special emphasis on the protective role exerted by this protein (Sakudo and Onodera, 2014).

Several contributions go down to the molecular scale and focus on the relationship between $\mathrm{PrP}^{\mathrm{C}}$ and cell signaling. The minireview by Roucou elaborates on the connection between $\operatorname{PrP}^{\mathrm{C}}$ dimerization, proteolytic processing and the recruitment of cell signaling cascades (Roucou, 2014). Ochs and Málaga-Trillo provide a perspective on the recurrent link between $\operatorname{PrP}^{\mathrm{C}}$-related signaling and src family kinases, in contexts ranging from embryonic cell adhesion to regulation of NMDA activity (Ochs and Malaga-Trillo, 2014). The protective function of $\operatorname{PrP}^{\mathrm{C}}$ against NMDA-dependent excitotoxicity is the focus of the review by Black et al, which also discusses the pathophysiological implications of this regulation as to ischemic injury, neuroinflammation, and Alzheimer's disease (Black et al., 2014). This last issue relates to the identification of $\operatorname{PrP}^{\mathrm{C}}$ as a cell-surface receptor for Abeta oligomers, and follow-up investigations on the contribution of $\operatorname{PrP}^{\mathrm{C}}$ to Abeta toxicity, which is summarized in the review by Watt et al. (2014). This review additionally focuses on the contribution of $\operatorname{PrP}^{\mathrm{C}}$ to zinc homeostasis, and discusses how age-regulated deregulation of the interplay between $\operatorname{PrP}^{\mathrm{C}}$, lipid rafts and zinc may contribute to Alzheimer's disease. The fate of $\operatorname{PrP}^{\mathrm{C}}$ during aging is further discussed in the review by Gasperini and Legname, which notably highlights the changes in the biochemical properties and lipid raft association of $\mathrm{PrP}^{\mathrm{C}}$ in aged animals (Gasperini and Legname, 2014).

Further zooming on the molecule itself, the review by Rezaei provides a global view of the biochemical and structural similarities between $\operatorname{PrP}^{\mathrm{C}}$, Doppel and Shadoo, as well as their specificities, in relation with their propensity to misfold (Rezaei, 2015).

Collectively, these works underscore the advance in our understanding of the functions exerted by the prion protein family and underlines their versatile roles according to the cellular context and interacting partners involved. Finally, they provide some future directions for further dissecting how the deregulation of these proteins functions can cause or contribute to pathological conditions. 


\section{REFERENCES}

Allais-Bonnet, A., and Pailhoux, E. (2014). Role of the prion protein family in the gonads. Front. Cell Dev. Biol. 2:56. doi: 10.3389/fcell.2014.00056

Black, S. A., Stys, P. K., Zamponi, G. W., and Tsutsui, S. (2014). Cellular prion protein and NMDA receptor modulation: protecting against excitotoxicity. Front. Cell Dev. Biol. 2:45. doi: 10.3389/fcell.2014.00045

Gasperini, L., and Legname, G. (2014). Prion protein and aging. Front. Cell Dev. Biol. 2:44. doi: 10.3389/fcell.2014.00044

Halliez, S., Passet, B., Martin-Lanneree, S., Hernandez-Rapp, J., Laude, H., Mouillet-Richard, S., et al. (2014). To develop with or without the prion protein. Front. Cell Dev. Biol. 2:58. doi: 10.3389/fcell.2014.00058

Makzhami, S., Passet, B., Halliez, S., Castille, J., Moazami-Goudarzi, K., Duschene, A., et al. (2014). The prion protein family: a view from the placenta. Front. Cell Dev. Biol. 2:35. doi: 10.3389/fcell.2014.00035

Martin-Lanneree, S., Hirsch, T. Z., Hernandez-Rapp, J., Halliez, S., Vilotte, J. L., Launay, J. M., et al. (2014). PrPC from stem cells to cancer. Front. Cell Dev. Biol. 2:55. doi: 10.3389/fcell.2014.00055

Mehrabian, M., Ehsani, S., and Schmitt-Ulms, G. (2014). An emerging role of the cellular prion protein as a modulator of a morphogenetic program underlying epithelial-to-mesenchymal transition. Front. Cell Dev. Biol. 2:53. doi: $10.3389 /$ fcell.2014.00053

Ochs, K., and Malaga-Trillo, E. (2014). Common themes in PrP signaling: the Src remains the same. Front. Cell Dev. Biol. 2:63. doi: 10.3389/fcell.2014.00063

Rezaei, H. (2015). Biochemical insight in to the prion protein family. Front. Cell Dev. Biol. 3:5. doi: 10.3389/fcell.2015.00005
Roucou, X. (2014). Regulation of $\operatorname{PrP}(C)$ signaling and processing by dimerization. Front. Cell Dev. Biol. 2:57. doi: 10.3389/fcell.2014.00057

Sakudo, A., and Onodera, T. (2014). Prion protein (PrP) gene-knockout cell lines: insight into functions of the PrP. Front. Cell Dev. Biol. 2:75. doi: $10.3389 /$ fcell.2014.00075

Watt, N. T., Griffiths, H. H., and Hooper, N. M. (2014). Lipid rafts: linking prion protein to zinc transport and amyloid-beta toxicity in Alzheimer's disease. Front. Cell Dev. Biol. 2:41. doi: 10.3389/fcell.2014.00041

Conflict of Interest Statement: The authors declare that the research was conducted in the absence of any commercial or financial relationships that could be construed as a potential conflict of interest.

Received: 20 January 2015; accepted: 23 January 2015; published online: 10 February 2015.

Citation: Mouillet-Richard S and Vilotte J-L (2015) Promiscuous functions of the prion protein family. Front. Cell Dev. Biol. 3:7. doi: 10.3389/fcell.2015.00007

This article was submitted to Cell Death and Survival, a section of the journal Frontiers in Cell and Developmental Biology.

Copyright (C) 2015 Mouillet-Richard and Vilotte. This is an open-access article distributed under the terms of the Creative Commons Attribution License (CC BY). The use, distribution or reproduction in other forums is permitted, provided the original author(s) or licensor are credited and that the original publication in this journal is cited, in accordance with accepted academic practice. No use, distribution or reproduction is permitted which does not comply with these terms. 